\title{
Vocational Education in the Era of Industry 4.0: An Indonesian Case
}

\author{
Muchlas Samani \\ Universitas Negeri Surabaya \\ Surabaya, Indonesia \\ msamani@unesa.ac.id
}

\begin{abstract}
In coping with the industrial era 4.0, the concept of 'competency' in vocational education must be converted into 'capability' to enable graduates engage with the latest work patterns. Vocational education must be flexible by the application of modular patterns combined with block system. It further becomes an integrative model that can incorporate both formal and non-formal education as well as both school and diploma level. Such an effective yet costless model is packed within CBVED model which is suitable for Indonesian context. This study implies that vocational education in Indonesia will have easy accesses to industrial partnerships through the implementation of CBVED model. Besides, the industrial partners will get the desired workforce easily.
\end{abstract}

Keywords-competence, capability, flexible, integrative, CBVED

\section{INTRODUCTION}

The definition of vocational education in this paper does not refer to Law Number 20 Year 2003, rather, refers to the international notion of education, whichs is preparing graduates to enter the workforce. In many literatures, such educational notion is usually called technical and vocational education and training (TVET). Thereby, it includes education at both school and college level and various forms of skill courses as well.

The rapid development of technology, especially information technology, has affected the industry era 4.0 which includes four main characteristics namely cyberphysical system, internet, cloud and cognitive computing. These four characteristics lead to very fundamental changes in work patterns in an industrial world. World Economic Forum predicts that until 2020 the currently existing core skills will have been lost because the work field does not need them any longer [1]. Along with that, the skills will emerge a new type of work that would require a different skill than what currently exists. Experts predict that changes in work patterns will continue to occur faster [2].

The change is a challenge especially for vocational education that prepares its graduates to be able to enter the rapidly changing employment. In regard to Indonesian context, Vocational High Schools, Polytechnics and Diploma Programs must prepare themselves for the challenge [3]. Because work patterns change very quickly, what students learn in school will possibly become obsolete when their graduates enter the work field. Therefore students should be able to transform what they learn in school to face a new work pattern.

Jim Clifton's article in his private blog entitled Universities: Disruption is Coming shows that Google and Ernst \& Young hire employees without requiring university degrees. Meaning, what have been learned at university is not too important to Google and Ernst \& Young companies. Both companies require other capabilities that are often extraneous to a major part of university curriculum. That's why Clifton says it's very possible that university will lose customers because what is taught does not match with what the world needs [4].

Clifton argues that vocational education faces a tough challenge in industry era 4.0. When university focuses on theoretical mastery only and never update it, vocational education that has been emphasizing on practical skills will be more tremendously affected. It is commonly known that automation has replaced many manual jobs, information technology has replaced clerical work and so on. The question is how vocational education must face the challenge and successfully prepare its graduates to enter the work field [4].

\section{METHOD}

As the work patterns continue to change fast [1], vocational education graduates should be prepared to be able to cope with those changes. They must be equipped with the ability to transform the skills they possess to fit the demands of new work patterns. What skills are needed in order to deal with those changes? According to existing literatures, there are several terms needed to be researched covering competence, capability, capacity and transferable skills.

In the context of vocational and professional education, Martin Mulder [5] mentions that professional competence is seen as general, integrated and internalized capabilities to deliver suitable and effective performance (e.g. problem solving, realizing innovation, and creating transformation) in a certain professional domain, job, role, organizational context and task situation. In other words, Martin Mulder interprets that professional competence includes the ability to perform self-transformation when facing new work patterns, although he does not explain the meaning of professional competence. 
When Mulder calls an ability as 'professional competence', Hase \& Davis and Corbel, Wheelahan, Forward \& Darwin rather call it as 'capability' [5-7]. Hase \& Davis [6] compare the notion of capability and competence by saying that people who know how to learn are categorized creative, having a high degree of selfefficacy, able to apply competencies in familiar situations and hard working. In comparison to competency, which only involves the acquisition of knowledge and skills, capability is a holistic attribute. According to Hase \& Davis, competency is only appropriate to face familiar situation while capability includes the ability to deal with certain situation [6].

What is capacity? Corbel, Wheelahan, Forward and Darwin refer it to an ability to deal with specific situation while competency is an ability to face familiar situation [7]. According to Hase \& Davis and Corbel, Wheelahan, Forward \& Darwin, the capability consists of two parts namely occupational competence and capacity [6,7]. Occupational competence is suitable for facing familiar situations and capacity is for new situation. That is the reason why Hase and Davis and Corbel, Wheelahan, Forward and Darwin suggest that vocational education provides a provision of capability and not competency to students [6,7].

In other sides, Nagele and Stalder call capacity as transferable skills or generic skills [8]. Consequently, skills themselves can be used to act efficiently in different real-life situations. However, Nagele and Stalder mention that transferable skills are parts of competence, in which Mulder also argues in the same path. The difference only lays on the terms $[5,8]$.

The term generic skills and occupational skills are also used by Kemdikbud (MoEC) to explain the concept of life skills [9]. Generic skills are seen as general and vital that are required by all employees to transfer from one field to another. Occupational skills or specific skills are definite and are only required for certain occupation.

That is, it can be concluded that there are two types of abilities in vocational education. First, competency or occupational competence [7] or specific skills [9] which are the ability related to certain areas of expertise and work patterns. Second, capacity [7] or transferable skills [8] or generic skills [9] is a wide-ranging ability required by all areas of expertise and all work patterns. If both are combined, Mulder [5] calls it professional competence, while Hase \& Davis and Corbel, Wheelahan, Forward \& Darwin name it capability [6,7].

In the context of vocational education, the two types of abilities are inseparable like the two sides of a coin. Students of vocational education must learn occupational competency according to their field of expertise and also must develop their capacity in order to be able to follow the changing of work patterns.

In order to develop capacity or transferable skills for vocational education students, it is important to know the aspects. The Economist study found five aspects namely problem solving, team working, communication, critical thinking, and creativity [2]. Meanwhile, Trilling and Fadel call the aspects as learning and innovation skills including critical thinking and problem solving, communication, collaboration, and creativity and innovation [10]. The National Association of Education names the skills as Four Cs with the same aspects as those mentioned by Trilling and Fadel [10,11].

Samani conducted a meta-analysis of various studies on $21^{\text {st }}$ Century skills and found a formula that workers must be able to solve problems creatively and work in harmony with colleagues [12]. In order to solve problems creatively, the persons should be able to search for data and information, conduct critical analysis of the information and think creatively to find the best solution. In order to maintain good relationships with colleagues, one must be able to communicate and cooperate well. Thus, the capacity aspects eventually lead to creative problem solving and harmonious cooperation, of which these two abilities determine the success of work in the industry era 4.0 [13].

\section{RESULT AND DISCUSSION}

The rapidly changing work patterns make us difficult to design a vocational education curriculum. Jorgen Moller argue that it will be not important how long an education lasts, the important thing is that graduates have the ability to suit the needs of the world of works [14]. Too specific vocational education will be easily obsolete. Meanwhile, vocational education that last too long has the risk that the learned skills will be obsolete when they graduate and enter the workforce.

In line with Moller, Yildan Wang suggests vocational education should be flexible, so that providing everyone with the widest opportunity to receive education, training or retraining in accordance with the needs of the world of work are important [13]. Modular pattern by considering learning area will be more effective [15]. The pattern implemented with a block system and supported by a good work culture will allow students to acquire full competence. The modular pattern applied to TVET in Germany can be a good material to refer [16].

If modular systems are implemented and combined with multi-entry and multi-exit systems (MEMES), the separation of formal and non-formal education in vocational education becomes irrelevant [17]. Moreover, using the principle of recognition of prior learning (RPL) combined with the application of Indonesia National Qualification Framework (KKNI) makes the separation of Vocational High School (SMK) and Polytechnic (Diploma) become less relevant. That is, vocational education in the Industrial era 4.0 becomes a flexible and integrated system [18].

A modular system combined with MEMES will make vocational education more flexible. Students can take the required modules in accordance to the job they want. They can retrain another module if the desired job requires it. Thus vocational education becomes very cost effective. As mentioned by Moller, vocational education should be understood as an investment either by the government or by students [14]. The effectiveness should be one of considerations in designing education, including vocational education [19]. The TAFE (Technical and Further 
Education) system in Australia can be a good comparison for the present study.

It should be essentially noted when modular systems and MEMES are implemented, the purpose of vocational education is no longer being ambiguous. Vocational education aims to prepare students to enter the workforce and not to continue their education to the university level. It does not mean that vocational education graduates are prohibited from continuing their education to university, because it is part of human right. However, the public should be informed that in vocational education, students do not have sufficient courses for continuing to pursue further education to university level.

\section{CONCLUSION}

Since vocational education aims to produce graduates who are ready to enter the word of work, then it is essential as part of economic development of a region or country [20]. Therefore it should be designed to produce the workforce especially those who are required in the related area [21]. In other words, vocational education development can be part of the regional development plan.

For Indonesia context with unique geographical conditions and very diverse economic potentials, the concept proposed by King and Palmer (2010) is very suitable. Vocational education development is tailored to the potential of the region, so that it can support each other. On the other hands, vocational education will ease students to get partners for industrial work practices, while the industry will also get a workforce that suits their needs. Based on that idea, the concept of commodity-based vocational education development (CBVED) can be applied to develop suitable vocational education for the produced commodity [3].

In CBVED concept, it does not mean that a region is prohibited to open vocational education that is not in accordance with its economic potential, but it is not a priority. The priority should be placed upon vocational education that supports the development of local economic potential. In coping with the practicality of the concept, junior high school graduates of a region are not prohibited from learning different vocational areas with their regional potential, but for that they have to do it in other areas. This concept will simultaneously reduce the urbanization caused by the difficulty of getting jobs in accordance with the area of expertise being studied.

\section{REFERENCE}

[1] World Economis Forum. (2016). The Future of Jobs: Employment, Skills and Workforce Strategy for the Fourth Industrial Revolution. Switzerland: World Economic Forum.

[2] The Economist, Intellegence Unit. (2015). Driving the Skills Agenda: Preparing Students for the Future. London: The Economist Report.

[3] Samani, Muchlas. (2018). "Empowering Pendidikan Vokasi" dalam Majalah Pembinaan Sekolah Menengah Kejuruan, Edisi Maret 2018.

[4] Clifton, Jim. (2016). Universities: Disruption is Coming. http://news.gallup.com/opinion/ chairman/191633/universitiesdisruption-coming.aspx. Downloaded January 15, 2017: $10.35 \mathrm{pm}$.

[5] Mulder, Martin. 2017. "Introduction" in Mulder, Martin (Ed) (2017). Competence-based Vocational and Professional Education: Bridging the World of Work and Education. Switzerland: Springer. Pp. 1-43.

[6] Hase, S \& Davis, L. (1999). From Competence to Capability: The Implications for Human Resource Development and Management.
Paper presented to Millennial challenges in management, education, cybertechnology, and leadership: Association of International. San Diego, 6-8 August 1999.

[7] Corbel, Chris, Leesa Wheelahan, Pat Forward, Stephen Darwin. (2014). Building Future Capabilities for Vocational Education. Victoria: Australia Education Union.

[8] Nagele, Christof and Barbara E. Stalder. (2017). "Competence and the Need for Transferable Skills" in Mulder (Ed) (2017). Competence-based Vocational and Professional Education: Bridging the World of Work and Education. Switzerland: Springer. Pp. 739754.

[9] Kemdikbud RI. (2003). Pendidikan Kecakapan Hidup: Konsep dan Pelaksanaannya. Jakarta: Kemdikbud.

[10] Trilling, Bernie \& Charles Fadel. (2009). 21st Century Skills: Learning fo Life in Our Times. San Francisco: John Wiley \& Sons Inc.

[11] National Association of Education. (2013). Preparing $21^{\text {st }}$ Century Students for a Global Sociaty. Washington DC: National Association of Education.

[12] Samani, Muchlas. (2014). Rethinking Education for 21st Century: An Indonesia Case. Paper presented at Asaihl International Conference at NTU Singapore, 2-3 December 2014.

[13] Wang, Yidan. (2012). Education in a Changing World: Flexibility, Skills, and Employbality. Washington DC: The World Bank

[14] Moller, Jorgen O. (2011). How Asia Can Shape the World: From Era of Plenty to the Era of Scarcities. Singapore: ISEAS Publishing.

[15] Gessler, Michael. (2017). "Area of Learning: The Shift Towards Work and Competence Orientation Within the School-based Vocational Education in the German Dual Apprenticeship Model" in Mulder, Martin (Ed). Competence-based Vocational and Professional Education: Bridging the World of Work and Education. Switzerland: Springer. Pp. 795-818.

[16] Samani, Muchlas. (2016). Pendidikan Vokasi di Jerman: Laporan Penelitian Komparatif. Surabaya: Universitas Negeri Surabaya.

[17] MoEC (Ministry of Education and Culture. (1997). Skills Rowards 2020 for Global Era. Jakarta: Ministry of Education and Culture.

[18] Perpres (Peraturan Presiden) Republik Indonesia No. 8 Tahun 2012.

[19] The World Bank. (2012). Putting Higher Education to Work: Skills and Research for Growth in East Asia. Washington DC: World Bank East Asia and Pacific Regional Report.

[20] King, Kenneth \& Robert Palmer. (2010). Planning for Teachnical and Vocational Skills Development. Paris: Unesco International Institute for Educational Planning.

[21] Sondergaard, Lars \& Mamta Murthi. (2012). Skills, Not Just Diploma: Managing Education for Results in Eastern Europe and Central Asia. Washington DC: The World Bank 